\title{
Effects of Remedial Instruction on Low-SES \& Low-Math Students' Mathematics Competence, Interest and Confidence
}

\author{
Der-Ching Yang ${ }^{1}$, Meng-Lung Lai ${ }^{2}$, Ru-Fen Yao ${ }^{1} \&$ Yueh-Chun Huang ${ }^{3}$ \\ ${ }^{1}$ Graduate Institute of Mathematics and Science Education, National Chiayi University, Chiayi, Taiwan \\ ${ }^{2}$ Department of Early Childhood Education, National Chiayi University, Chiayi, Taiwan \\ ${ }^{3}$ Graduate Institute of Educational Administration and Policy Development, National Chiayi University, Chiayi, \\ Taiwan
}

Correspondence: Der-Ching Yang, Graduate Institute of Mathematics and Science Education, National Chiayi University, Chiayi, Taiwan. E-mail: dcyang@mail.ncyu.edu.tw

Received: October 23, 2013

Accepted: November 6, 2013 Online Published: February 12, 2014

doi:10.5539/jel.v3n1p1

URL: http://dx.doi.org/10.5539/jel.v3n1p1

\begin{abstract}
This study aimed to examine the effects of remedial instruction on low-SES \& low-math first graders' basic mathematics competence as well as their interest and confidence in mathematics learning. Fourteen participants of low-SES \& low-math were selected from two classes totaling fifty-seven first graders at a public elementary school in central Taiwan. Results show that remedial instruction conducted during the study successfully improved the low-SES \& low-math students' mathematics competence and enhanced their interest and confidence in mathematics. Remedial instruction in the form of story contexts conducted through small group collaboration with manipulatives appeared to improve low-SES \& low-math students' mathematics learning. Implications related to remedial instruction for low-SES \& low-math students are discussed.
\end{abstract}

Keywords: low-SES \& low-math students, Mathematics interest and confidence, Mathematics learning, remedial instruction

\section{Introduction}

\subsection{Introduce the Problem}

Mathematics for all has been internationally considered a key issue of mathematics education (Deschenes, Cuban, \& Tyack, 2001; Kilpatrick, Swafford, \& Findell, 2001; NCTM, 2000). Every student should not only have the right to approach mathematics equally, but should also learn and understand mathematics equally. School teachers must ensure that all students receive equivalent education, especially those students who need extra attention. However, the population of Taiwanese students in low social economic status (SES) families with a low performance in mathematics continues to increase (Ministry of Education Taiwan, 2010). Low-SES is defined as having a yearly income lower than 122,928 NT dollars (about 4,100 US dollars) (Ministry of Interior Social Affairs Taiwan, 2012). At the same time, results of the Programme for International Student Assessment (PISA) (OECD, 2009) do show that 15-year-old students in Taiwan performed at the top on mathematics tests; however, there still are a high percentage of these students that belong to the low mathematics achievers. For example, the results of the Trends in International Mathematics and Science Study (TIMSS) show a big gap exists between high-SES and low-SES in Taiwan (Akiba, LeTendre, \& Scribner, 2007; Mullis, Martin, Gonzalez, \& Chrostowski, 2004; Mullis, Martin \& Pierre, 2009). Data show that many low achievers, especially in mathematics, are from low-SES families, therefore, they need extra help to promote their mathematics ability (Ministry of Education Taiwan [MET], 2010).

Previous studies indicate that low-SES students and low achievers in mathematics who are at risk in mathematics performance need more care and assistance; unfortunately, they usually do not receive enough attention from researchers and instructors (Cramer, Post, \& delMas, 2002; Empson, 2003). Some action, thus, needs to be taken to tackle this rarely-visited issue. In addition, several earlier studies show that low-SES students' mathematics performance is highly related to their mathematics interest and confidence (Hannula, Maijala, \& Pehkonen, 2004; Köller, Baumert, \& Schnabel, 2001). Increasing interest and confidence in these low-SES students could be used 
to enhance their performance in mathematics. Therefore, two research questions were developed to address this issue:

1) Does remedial instruction improve low-SES \& low-math students' interest and confidence in mathematics learning, and thus enhance their mathematics competence?

2) Specifically, what elements of the remedial instruction trigger low-SES \& low-math students' interest and confidence toward mathematics learning?

\subsection{The Importance of Equality in Mathematics for All Students}

Accomplishing equality in mathematics education is an important challenge to school teachers, mathematics educators, and researchers (Bartell, 2011; NCTM, 2000; Schoenfeld, 2002). This has especially become a key issue in Taiwan due to the increase of low-SES students during the past 10 years (Ministry of Education Taiwan, 2010). For example, although 4th- and 8th-graders in Taiwan ranked high on TIMSS mathematics achievements (Mullis, Martin, Gonzalez, \& Chrostowski, 2004; Mullis, Martin \& Pierre, 2009), the performance gap between high-SES and low-SES continues to increase. Therefore, supporting more mathematics learning opportunities for low-SES students to achieve mathematics equality has been highlighted by both school teachers and mathematics scholars in Taiwan (Ministry of Education Taiwan, 2010) as well as other countries from Europe (Morais \& Neves, 2001; Skovsmose \& Valero, 2002), North America (Bartell, 2011; Gutstein, 2003; Lubienski, 2007; NCTM, 2000; Schoenfeld, 2002), and Asia (Yao \& Yang, 2010). Although, teaching mathematics to low-SES students is limited in Taiwan and other countries, an increasing number of research studies still suggest that this kind of pedagogy can provide a solution to the imbalance of equality in mathematics education (Bartell, 2011; Gutstein, 2003; Lubienski, 2007; Skovsmose \& Valero, 2002). Remedial instruction, for example, has been suggested to provide more opportunities for approaching mathematics learning (Yao \& Yang, 2010).

\subsection{Related Studies on Low-SES Students' Mathematics Learning}

Lubienski (2003) argues that the study of social class issues can be taken as classist but also provides positive reasons for these diversities; still, obviously we cannot neglect the problems lower classes reflect on education. Research also shows that working-class parents educate children straightforwardly, and on the other hand middle-class parents prefer to guide children step by step (Walkerdine, 1998). To be more specific, working-class parents want to teach children in as direct a way as possible. Morais and Neves (2001) argue that social class does have the power to influence students' ability on understanding the meaning of problems. Moreover, Lubienski (2007) argues that the relation between social class and students' performance on situational mathematics problems must be considered due to the overwhelming evidence shown in previous research of a correlation between these two variables. Studies by Morais and Neves (2001) discovered that for examinations in England and Wales situational mathematics problems, rather than abstract mathematics problems, could trigger an effect on disparate classes. Quantities of data show that low-SES students focus on the context and mathematics performance, which is beyond a researcher' s expectation (Lubienski, 2007). In addition, reform-minded practices are probably helpful for low-SES students (Boaler, 2002; Lubienski, 2007).

Previous research has indicated that SES is a key factor to success in school. Middle-class children generally outperform children from low-income families on some number and arithmetic tasks (e.g., Arnold \& Doctoroff, 2003; Starkey, Klein, \& Wakeley, 2004). Students identified as low- SES very likely enter school with lower achievement in mathematics than middle- or high-SES students (Arnold \& Doctoroff, 2003). In addition, Jordan and Levine (2009) found that children from low-income families perform substantially worse in math than their counterparts from higher-income families. For example, often due to their own learning difficulties, parents in low- income families provide less support for academic learning in the form of monitoring, scaffolding, and expectations (Entwisle \& Alexander, 1996; Pogrow, 2009). In contrast, middle-class parents tend to provide a broader range of activities and more complex tasks, and they do so more often than working-class parents (Jordan \& Levine, 2009; Morais \& Neves, 2001).

\subsection{Remedial Instruction for Low-SES and Low-Math Students}

Remedial instruction should be provided for students who have performed poorly in mathematics to ensure their future academic success (Finnish National Board of Education, 2004). Arnold, Fisher, Doctoroff, and Dobbs (2002) found that children receiving intervention not only improved their mathematics skills but also showed an increased interest in mathematics. Several studies (National Research Council, 2001; Stein, Remillard \& Smith, 2007; Yang \& Li, 2008) suggest that an opportunity to learn plays a key role in promoting low achieving students' mathematics performance. Therefore, remedial instruction can provide low-SES and low achievement in mathematics students more opportunities to learn mathematics. Given the recognition of the importance of 
confidence and interest toward the learning of mathematics, determining how to foster low-SES and low achievement in mathematics students' confidence and interest toward the learning of mathematics has thus become urgently necessary.

Earlier studies (Cramer et al., 2002; Empson, 2003) suggested mathematics instruction that focused on posing story problems for children to solve by using their own ways and appropriate use of concrete teaching materials promoted low achieving children' s mathematics learning. In addition, several studies (Empson, 2003; O' Connor, 2002; Strom, Kemeny, Lehrer, \& Forman, 2001; Yang, 2006) found that students' participation in classroom discourse, including small-group collaboration and whole-class discussion, will promote children' $s$ mathematics confidence and mathematics learning. Even though Lubienski (2007) indicated that low-SES students "did not experience the feelings of empowerment from whole-class discussions and opened-problems" (p. 20), this study integrated the use of story problems, concrete teaching materials, and encouraged low-SES \& low-math students to participate in small-group collaboration, whole-class discussion, and present their problem-solving methods. Specifically, this study used story problems and concrete teaching materials to increase student motivation and mathematics learning (Cramer et al., 2002; Empson, 2003; Yang, 2006). In addition, small-group collaboration and whole-class discussion were applied to encourage participation (Empson, 2003; O' Connor, 2002; Yang 2006). The purpose of this study was to investigate whether remedial instruction through the above-mentioned approaches would be effective in enhancing low-SES \& low-math students' confidence and interest in mathematics.

\subsection{Confidence, Interest, and Mathematics Performance among Low-SES \& Low-Math Students}

Previous studies (e.g., Arnold \& Doctoroff, 2003; Jordan \& Levine, 2009) have suggested that children from families with low-SES experience a high rate of failure in terms of their academic performance. Arnold and Doctoroff (2003) found that poor mathematics trajectories in low-SES children begins very early, and therefore, this phenomenon should receive specific attention and sufficient resources may be needed to reduce this related gap. Indeed, low-SES is a powerful predictor of children' s academic performance (Jordan \& Levine, 2009; Pogrow, 2009), and the influence of low-SES on children' s mathematics skills has been found in several studies, such as with symbolic addition/subtraction (Huttenlocher, Jordan, \& Levine, 1994) or the three-term inverse principle (Lai, Baroody, \& Johnson, 2008). In addition, confidence and interest are crucial to low-SES students' learning of mathematics and greatly influence their mathematics performance (Hannula et al., 2004; Köller et al., 2001). Hannula et al. (2004) indicated that mathematics achievement was significantly predicted by students' confidence. Stipek and Ryan (1997) conducted a study on 262 low-SES kindergarteners and found that interest variables such as child worry scale affected their participants more strongly than their low-SES counterparts.

Thus, now that the importance of confidence and interest toward the learning of mathematics has been recognized, for example with fraction learning (Cramer et al., 2002; Empson, 2003) and pre-algebra (Huttenlocher et al., 1994; Lai, Baroody, \& Johnson, 2008), the main purpose of our study was to investigate whether remedial instruction could be effective in improving low-SES and low-math students' confidence and interest in mathematics learning.

\section{Method}

\subsection{Participants}

Fifty-seven $1^{\text {st }}$ graders ( 31 boys, 26 girls; Mean $=6.8$ years old) from a public elementary school in central Taiwan participated in this study. This school is located in a relatively poor neighborhood made up of many low-SES students. There are 24 out of 57 students belonging to the low-SES students and 33 students are not belonging to the low-SES students (General learners). According to the pre-test (basic mathematics competence test), 14 out of 24 low-SES students scored at the bottom 30\% (In this study, we defined these students as low-SES \& low-math students) in the pretest and were thus considered to receive the remedial instruction after their parents' permission. The remaining 10 low-SES students and 33 general learners do not receive the remedial instruction.

\subsection{Instruments}

Basic mathematics competence test (BMCT). This instrument included 10 items with 20 questions (see Appendix 1) in which four topics (number and operation, geometry, measurement, and pre-algebra) were covered and served as the pre-test and post-test. The Cronbach's $\alpha$ coefficient for the instrument is .821 (the Cronbach's $\alpha$ for the four subtopics number and operation, geometry, statistics, and pre-algebra are $0.76,0.69,0.63$, and 0.71 , respectively). The BMCT was designed based on the students' mathematics class textbook and was used to examine their basic mathematics concepts and skills for grade 1 level. 


\subsubsection{Mathematics Interest and Confidence (MIC) Questionnaire}

The MIC questionnaire was designed by the researchers and used to measure the participants' interest and confidence in mathematics learning. This questionnaire included two parts: mathematics learning interest and mathematics learning confidence. There are thirteen questions in the mathematics learning interest section, which includes four aspects: feeling, cognition, expectation and action (e.g., Question 7: I hope I can have more math classes). The mathematics learning confidence section was composed of seventeen questions encompassing six aspects: behavior choice, work performance, thinking model, emotional reflection, mastery experience, observed learning, physical and mental status, and others' attitude (e.g., Question 16: What would I do if I raised my hand to ask a question and my classmates laughed at me?). Therefore, the MIC contained 30 three-point Likert scale questions in total. A three-point Likert scale was used instead of a five-point Likert scale in order to make it easier for the $1^{\text {st }}$-grader participants to make decisions regarding the items. The Cronbach' s $\alpha$ coefficient for the questionnaire was .843. The higher scores represented higher interest and confidence in mathematics learning. Three mathematics educators and three elementary school teachers validated this questionnaire and agreed unanimously that the questionnaire was appropriate to measure students' interest and confidence in mathematics learning.

\subsection{Procedure}

This study was conducted in three stages:

1) During the first stage, all participants were asked to individually complete the paper-and-pencil pretest within 40 minutes and the MIC questionnaire within 40 minutes. For the former, students were asked to write down the solution (process) and answer.

2) During the intervention stage, the researchers and four well-trained graduate students were responsible for the remedial instruction that lasted for a period of eight weeks. Small groups of three or four participants were formed to collaboratively solve the given problems with the manipulatives available. Participants were asked to complete worksheet exercises.

3) During the third stage, the paper-and-pencil posttest and the MIC questionnaire were administered again one week after the remedial instruction. The procedures of the implementation of the paper-and-pencil posttest and the MIC questionnaire were the same as those in the first stage.

\subsection{Treatment}

Duration of the remedial instruction: The fourteen low-SES \& low-math students received a 40-minute session twice a week (Tuesdays at noon and Wednesday mornings) for a period of eight weeks in a quiet room.

Teaching materials. The entire remedial instruction consisted of 16 sessions in which four quantitative concepts, "line or curve differentiation", "number composition and decomposition", "ordinal meaning of number", and "the meaning of equal sign" were covered. The target concepts were all integrated into story problems, which were introduced in the beginning of each session.

Three to four activities were run for each lesson during the remedial instruction. Take the "line-curve differentiation" lesson for example, students were told a story about Doraemon (an animated cartoon character) which served to activate their desire to learn. During story telling, the teacher posed a question: "Doraemon needs some help to pass through a broken bridge. By drawing can you help Doraemon to fix this broken bridge? After small-group discussion, some students drew a curve while the others drew a straight line. Then the teacher would explain the meaning of the line based on students' responses. In other words the teacher encouraged students to discuss the difference between a line and a curve, and then asked the students to provide their answers. In order to ensure these participants reliably and correctly differentiated the line from the curve, they were then asked to identify whether a snake on the other side of the bridge is curve or not.

The nature of remedial instruction: The remedial instruction included four parts. First, the beginning of each activity included story telling to elicit students' attention and motivation. Second, following the story, a key question was posed and children were encouraged to have small-group collaboration to solve the problem. Third, during small-group collaboration, children were encouraged to use concrete materials to help in solving the problem and develop mathematical concepts. Finally, during whole-class discussion, each group was encouraged to share their ideas about how they solved the problem. 


\subsection{Data Analyses and Scoring}

BMCT: Both response accuracy (correctness of an answer) and scoring solution process (strategy or procedure used to obtain answer) were noted and used to score performance. Accuracy was scored as correct (1 point) or incorrect (0 points).

MIC questionnaire: Each item in the questionnaire included three choices. The first choice, the strongest in interest or confidence, was rated 3 points, the second choice, neutral, was rated 2 points, and the third choice, the weakest, was rated 1 point.

Treatment: The qualitative data collected from the remedial instruction included transcripts from the videotapes for the 16 activities with teachers' and observers' field notes. Two math educators independently reviewed these transcripts and videotapes. These initial reviews produced categorization agreement on more than $95 \%$ of the students' responses. The transcripts and videotapes which have discrepancies were reexamined and discussed by all seven math educators until a consensus was reached.

\section{Results}

\subsection{Low-SES \& Low-Math Students' Changes on MIC and BMCT}

The means and standard deviations of MIC and BMCT before and after the remedial instruction for the three different groups are shown in Table 1. Before receiving remedial instruction, the low-SES \& low-math students had lower mean scores on the MIC (72.43) and the BMCT (51.67) than both the low-SES students without receiving the remedial instruction $(82.2 \& 84)$ and general learners $(76.91 \& 75.76)$. However, after the remedial instruction, these low-SES \& low-math students' scores on the MIC were similar to that of the general students. The mean posttest scores on the MIC by the general learners were very similar to their pretest scores, in comparison to the low-SES \& low-math students that showed improvement. Evidently, aside from improvement on the BMCT, remedial instruction can also enhance low-SES \& low-math students' mathematics interest and confidence levels.

Table 1. Mathematics interest and confidence and Mathematics achievement means and standard deviations across groups before and after remedial instruction

\begin{tabular}{lllll}
\hline \multirow{2}{*}{ Group } & \multicolumn{3}{l}{ MIC $^{\mathrm{a}}$ BMCT $^{\mathrm{b}}$} \\
\cline { 2 - 5 } & Mean (SD) & \multicolumn{3}{l}{ Mean (SD) } \\
\cline { 2 - 5 } & Before & After & Before & After \\
\hline Low-SES students with low achievement in & 72.43 & $78.22^{*}$ & 51.67 & $65.47^{*}$ \\
mathematics (14) (receiving remedial instruction) & $(7.45)$ & $(9.07)$ & $(10.84)$ & $(17.42)$ \\
Low-SES learners (10) (without receiving remedial & 82.2 & 81.4 & 84.0 & 85.47 \\
instruction) & $(4.66)$ & $(4.93)$ & $(7.00)$ & $(8.23)$ \\
General learners (33) & 76.91 & 77.61 & 75.76 & 75.74 \\
& $(10.04)$ & $(8.55)$ & $(19.88)$ & $(21.68)$ \\
Total sample (57) & 76.74 & 78.42 & 71.3 & 74.9 \\
& $(9.17)$ & $(8.17)$ & $(19.94)$ & $(19.81)$ \\
\hline
\end{tabular}

Note. MIC and BMCT stand for Mathematics Interest and Confidence, and Basic Mathematics competence Test, respectively.

* indicate $\mathrm{p}<.05$

Results also indicate that low-SES \& low-math students receiving remedial instruction scored significantly higher on the MIC and BMCT in the posttest than in the pretest via t-test $(\mathrm{p}<.05)$, which implies that remedial instruction was effective and helpful in promoting low-SES \& low-math students' mathematics interest and confidence as well as mathematical competence. 


\subsection{Pretest and Posttest Differences on the MIC and the BMCT between Three Groups}

Table 2 summarizes the Mann-Whitney $U$ test results of the pretest and posttest differences on the MIC and the BMCT for low-SES \& low-math students who received remedial instruction and general learners. Data shows a statistically significant difference between the low-SES \& low-math students who received remedial instruction and general learners on the MIC $(\mathrm{p}=0.026, \eta 2=.087)$ and the BMCT $(\mathrm{p}<.001, \eta 2=.103)$. The general learners greatly outperformed the low-SES \& low-math students on all assessments. Surprisingly, the differences between general learners and low-SES \& low-math students on the MIC disappeared and the differences on the BMCT decreased after remedial instruction. These results indicate that the remedial instruction has a positive effect on interest and confidence in mathematics as well as their basic mathematics learning for the low-SES \& low-math students.

Table 2. The differences of MICand BMCT between general learners and low-SES and low-Math students (received remedial instruction) by Mann-Whitney U test

\begin{tabular}{|c|c|c|c|c|}
\hline & \multicolumn{2}{|l|}{ MIC } & \multicolumn{2}{|l|}{ BMCT } \\
\hline & \multicolumn{2}{|l|}{$\mathrm{U}(p)$} & \multicolumn{2}{|l|}{$\mathrm{U}(p)$} \\
\hline & Before & After & Before & After \\
\hline \multicolumn{5}{|l|}{ General learners } \\
\hline $\begin{array}{l}\text { vs } \\
\text { Low-SES and low-mathematics } \\
\text { students (received remedial } \\
\text { instruction) }\end{array}$ & $\begin{array}{l}135.500 \\
\left(.026^{*}\right)\end{array}$ & $\begin{array}{l}204.5 \\
(.537)\end{array}$ & $\begin{array}{l}36.000 \\
\left(0.000^{* * *}\right)\end{array}$ & $\begin{array}{l}118.500 \\
\left(.009^{* *}\right)\end{array}$ \\
\hline$\eta^{2}$ & .087 & & .103 & \\
\hline
\end{tabular}

Note. ${ }^{*} \mathrm{p}<.05,{ }^{* *} \mathrm{p}<.01,{ }^{* * *} \mathrm{p}<.001$

In summary, the results above imply that remedial instruction could promote low-SES \& low-math students' confidence and interest, and basic mathematics competence, as compared to general learners.

Factors of remedial instruction influencing low-SES \& low-math students' overall mathematics interest and confidence in mathematics learning

The quantitative data shows that remedial instruction successfully promotes low-SES \& low-math students' overall interest and confidence in mathematics learning. What factors of remedial instruction were most helpful to the low-SES \& low-math students' mathematics interest and confidence? Based on the analyses of the qualitative data, the reasons why remedial instruction is effective are fourfold: 1) integrating story problems into remedial instruction, 2) appropriately utilizing concrete materials in instruction, 3) offering low-SES \& low-math students' opportunities to learn mathematics, and 4) forming small groups to solve math problems.

\subsection{Story Problems Were Integrated into the Remedial Instruction}

Before the remedial instruction, low-SES \& low-math students were usually silent and did not vocalize or contribute to class discussion in mathematics classes. This study selected a popular cartoon for each class period to entice students to pay more attention during mathematics lessons. Results showed that the stories worked well. For example, the following vignettes illustrate the promotion of students' motivation and interest:

\section{Episode 1}

Lesson 1' s topic focused on helping low-SES \& low-math $1^{\text {st }}$-graders to differentiate between a "straight line" and a "curve." Before posing a mathematics problem, the teacher began to tell a story about the cartoon character Doramon. Many children paid attention to the teacher and wanted to share their thoughts. For example:

T: One day, Jing-xiang and Pang-Hu (names of characters) did not want to do their homework but decided to play the game, "Bamboo Dragonfly" in the park. They tried to make the "Bamboo Dragonfly" to fly in the air. Unfortunately, Jing-xiang' s Bamboo Dragonflies flew to the other side of the park. The only way to get there was to cross a broken bridge... 
S: Me! Me! Me! (Many students raised their hands and said: "Me!" They wanted to share their ideas.)

The teacher reflected: "All of the students were quiet when listening to me tell the story about Doramon. In the beginning I was so surprised to discover that my kids liked listening to the story." The teacher continued: "Many students raised their hands and shared their ideas [and] they seemed to be attracted by the story." Moreover, students also reported to teacher: "Dear teacher, I love this story. It is interesting." The teacher felt encouraged. The teacher continued:

$\mathrm{T}:$... The only way to get there is cross the broken bridge. Please draw a bridge (draw a line) and help them reach the other side of the park.

The problem posed through story telling stimulated students' attention and interest to understand the problem.

\subsubsection{Appropriately Utilized Concrete Materials during Instruction}

During remedial instruction, concrete representation seems an effective and important teaching method to help children develop an understanding of mathematics. The following example shows how one teacher utilized a concrete object (a real straight line and a real curved line) to help low-SES \& low-math students differentiate between a curve and a straight line.

\section{Episode 2}

Teacher: What is this? (The teacher used a cord to make a straight line

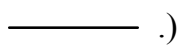

Many students responded: A straight line.

Teacher: How do you know?

[Unlike previous silent mathematics classes, several students raised their hands and wanted to share their ideas.]

S2: The line is straight and not curved. So, it is a straight line.

Teacher: How about this $\sim$ ?

Students: A curved line.

Teacher: Why?

S11: There are several bends. It looks like a road where you would need to make turns. So it is not a straight line. Teacher: Very good! What is this ?

S5: It has a big bow. It is not a straight line.

The above episode shows that the teacher used different concrete objects (cords) to represent different pictures (e.g., — $\backsim$, or $\bigcirc$ ) to help children understand the concept of a straight line. This indicates that a concrete object is very helpful in developing children's understanding of straight lines and curved lines through visual representations.

\subsubsection{Remedial Instruction Supported Low-SES \& Low-Math Students' Opportunity to Learn Mathematics}

During remedial instruction, teachers tried to encourage low-SES \& low-math students to answer or inquire about questions presented to them, which supported the students in sharing and presenting their thoughts and problem solving methods to peers. An example is illustrated below.

\section{Episode 3}

Teacher: I put two coins on the right side of the seesaw. I put another six coins on the right side of the seesaw. How many total coins are there on the right side of the seesaw?

Several students: Eight.

Teacher: Okay, now I' m putting three coins on the left side of the seesaw. How many coins do I need to put on the left side of the seesaw to balance the seesaw?

S6: One, two....five.

Teacher: S6 can you explain why?

S6: I put five coins on this side and then it balanced. Now they are the same.

The above episode indicates how the teacher led her students to solve a problem step by step. In addition, students reflected: "This kind of teaching gives me a chance to learn mathematics better because teachers always encourage us to solve the problem based on our thinking and encourage us to share our ideas. When I listened to 
other students' explanations, I am easy to get it and understand." This episode shows that a teacher can continue to support low-SES \& low-math students and encourage them to share their mathematical thought processing by giving them the opportunity to learn and share mathematics. This process can promote these students' interest and confidence in learning mathematics.

\subsubsection{Small Group Cooperation}

We divided participants into several small groups of four to five students. During remedial sessions, the teacher always encouraged the children to participate in small-group discussion, come up with a collective answer, and then prepare to back up their answer with explanation and reasoning. This process worked very well because students had a chance to share their ideas and help each other out. An illustration is given below in Episode 4.

\section{Episode 4}

Teacher: I put two coins on the right side of the seesaw and put three coins on the left side of the seesaw. Now, I put six more coins on the right side of the seesaw. What's happening? Please discuss in your small groups.

S6: The left side of the seesaw is lighter.

S9: What do you mean?

S6: I don' t know how to explain.

S1: If we want to make the seesaw balanced, then both sides need to have the same amount of coins.

S6: Can you explain that again?

S1: Do you remember when we played with the seesaw on the playground? If my weight is heavier than yours, then my side of the seesaw will go down. So, if we want to make the seesaw be balanced, then the right side and left side should have the same amount of coins.

S6: I understand.

S1: Right now there are eight coins on the right side of the seesaw.

S9: There are three coins on the left side of the seesaw. So...

S15: I guess we should put three...

S6: Four...

S2: We can try it. Put three coins on the left side.

S6: The right side of the seesaw is still heavier.

S6: How about four?

S2: The right side of the seesaw is still heavier.

S2: You see! I put five coins, and that could make the seesaw balance.

S15: So the answer is five!

The episode above showed that students in the small group, through discussion and collaboration, learned to rely on each other. Moreover, students were able to share their ideas, pool their thinking, question and help each other, and discuss their problem solving methods to decide on the right answer. This implies that small group cooperation is a good approach for helping students to learn mathematics. In addition, data shows that no students could answer the pre-algebra questions, such as question 8. (3) $3+2=1+(\quad$ ) and (4) $6+3=10-(\quad$ ) before the remedial instruction. However, after the remedial instruction, 10 and 9 students correctly answer the above questions, respectively. This indicates that small-group discussion and cooperation help them make sense the meaning of equal sign.

In summary, the above analyses imply that four major factors, including applied story problems (to lead instruction), appropriately utilized concrete materials, support of low-SES \& low-math students' opportunity to learn mathematics, and small group collaboration, influenced the low-SES \& low-math students' interest and confidence in mathematics learning.

\section{Discussion}

This study investigated the change of low-SES \& low-math students' interest and confidence, and mathematics competence after receiving remedial mathematics instruction. Although the remedial instruction was implemented over only 16 sessions (40 minutes for each session) and limited to fourteen 1st-grade low-SES \& 
low-math students, the improvement of these 1st graders after remedial instruction is unmistakable. The major findings of the study are twofold.

Firstly, the results clearly show that story problems and the use of concrete materials integrated into remedial instruction are extremely helpful in promoting low-SES \& low-math students' mathematics interest, confidence, and mathematics competences. These students benefited from remedial instruction, which confirms several earlier studies (Cramer et al., 2002; Köller et al., 2001; Marsh, Trautwein, Lüdtke, Köller, \& Baumert, 2005) where remedial instruction was shown to improve low-SES \& low-math students' confidence, interest, and performance in mathematics.

Secondly, as we mentioned previously, remedial instruction is effective due to four factors: applying story problems, appropriately utilizing concrete materials, providing low-SES \& low-math students with an opportunity to learn, and forming small groups to solve mathematics problems, were found effective in enhancing the interest and confidence of low-SES \& low-math students. Regarding the first factor, this study integrated story problems into remedial instruction, which attracted and retained the low-SES \& low-math students' attention as well as boosting their interest in mathematics learning. This confirms earlier studies (Ameis, 2002; Bainbridge \& Pantaleo, 1999; NCTM, 2000; NRC, 2001; Ruddell, 1999) that showed story problems can be an effective catalyst in promoting low-SES \& low-math students' interest in mathematics and cause them to pay more attention to the learning of mathematics. Second, the appropriate use of concrete materials plays an important role in helping children develop a better understanding of mathematical concepts. These results are also consistent with previous studies (Cramer, Post, \& delMas, 2002; Green, Piel \& Flowers, 2008; Kennedy, 2000) where concrete materials were shown to be an effective and important teaching material for the development of mathematics understanding. Third, previous studies (e.g., Hiebert \& Grouws, 2007; Stein et al., 2007; Yang \& Li, 2008) have also highlighted that all students should be given an equal opportunity to learn mathematics. This study showed that remedial instruction can significantly enhance low-SES \& low-math students' interest and confidence in mathematics learning, due to the fact that an opportunity to learn was presented to these students. It seems reasonable to believe that the opportunity to learn not only plays a key role in promoting low-SES \& low-math students' performance, but also in enhancing their interest and confidence in mathematics learning (Hiebert \& Grouws, 2007; Stein et al., 2007). If we provide sufficient learning opportunities to low-SES \& low-math students, they are most likely to learn just as well as general students. Fourth, this study also found that small group collaboration provided low-SES \& low-math students more opportunities to discuss and share their thinking with peers. During small group discussion, the low-SES \& low-math students were able to solve problems together and learn from each other, consistent with the findings of previous studies (Fraivillig, 2001; Yang \& Wu, 2010).

\section{Conclusion}

Equality in mathematics access has generally been considered an important issue in mathematics education (Lubienski, 2007; Nasir \& Cobb, 2007; NCTM, 2000; NRC, 2001). Supporting opportunities to learn mathematics for all students, especially for low-SES \& low- math students, is a key approach to implement equality in mathematics. Remedial instruction is an important strategy for low-SES \& low-math students to access mathematics learning and should be provided for students who have performed poorly in mathematics to ensure their future academic success (Finnish National Board of Education, 2004). Results of this study showed that remedial instruction successfully improved low-SES \& low-math students' mathematics competence and enhanced their interest and confidence in mathematics. Remedial instruction provided through story contexts that encourages small group collaboration appeared to improve the low-SES \& low-math students' mathematics learning. This finding supports earlier studies (Bottge et al., 2007; Empson, 2003; O' Connor, 2002; Strom et al., 2001; Yang 2006; Yang \& Wu, 2010) in that students' participation in classroom discourse, including small-group collaboration, sharing problem-solving strategies, and whole-class discussion, will promote low-SES \& low-math students' mathematics confidence, interest, and mathematics competence.

The implication of this study is that appropriate remedial instruction offers students an opportunity to learn, which in turn improves the low-SES \& low-math students' interest and confidence in learning mathematics as well as their mathematics competency. In addition, this study connected research to practice by showing how low-SES \& low-math students' mathematics ability can be improved. Remedial instruction is a necessary strategy to improve low-SES \& low-math students' mathematics learning. This confirms the statement of Marsh et al. (2005) that the most effective strategy in retaining students' progress is to improve interest and achievement simultaneously. 


\subsection{Suggestions for Further Studies}

One important issue not examined in this study relates to the durability of change in mathematics competence, mathematics confidence and interest that resulted from the short-term remedial instruction. Will students retain what they improved regarding mathematics competence, confidence and interest 1 or 2 years after their learning experience? A longitudinal study should be done to obtain an answer to this question.

\section{Acknowledgment}

The authors thank all the reviewers and Editor for their comments. This paper is part of a research project supported by the NSC, Taiwan with grant no. NSC 97-2511-S-415 -002-MY2. Any opinions expressed here are those of the authors and do not necessarily reflect the views of the NSC, Taiwan.

\section{References}

Akiba, M., LeTendre, G. K., \& Scribner, J. P. (2007). Teacher quality, opportunity gap, and national achievement in 46 countries. Educational Researcher, 36(7), 369-387. http://dx.doi.org/10.3102/0013189X07308739

Ameis, J. A. (2002). Stories invite children to solve mathematical problems. Teaching Children Mathematics, $8(5), 260-264$.

Arnold, D. H., \& Doctoroff, G. L. (2003). The early education of socioeconomically disadvantaged children. Annual Review of Psychology, 54, 517-545. http://dx.doi.org/10.1146/annurev.psych.54.111301.145442

Arnold, D. H., Fisher, P. H., Doctoroff, G. L., \& Dobbs, J. (2002). Accelerating math development in Head Start classrooms. Journal of Educational Psychology, 94, 762-770. http://dx.doi.org/10.1037/0022-0663.94.4.762

Bainbridge, J., \& Pantaleo, S. (1999). Learning with literature in the Canadian elementary classroom. Edmonton, Alta: Duval House Publishing.

Bartell, T. G. (2011). Learning to teach mathematics for social justice: Negotiating social justice and mathematical goals. Journal for Research in Mathematics Education, Special Equality Issue, 1-35.

Boaler, J. (2002). Learning from teaching: Exploring the relationship between reform curriculum and equity. Journal for Research in Mathematics Education, 33(4), 239-258. http://dx.doi.org/10.2307/749740

Bottge, B. A., Rueda, E., Serlin, R. C., Hung, Y-H., \& Kwon, J. M. (2007). Shrinking achievement differences with anchored math problems: Challenges and possibilities. Journal of Special Education, 41(1), 31-49. http://dx.doi.org/10.1177/00224669070410010301

Cramer, K. A., Post, T. R., \& delMas, R. C. (2002). Initial fraction learning by fourth-and fifth-grade students: A comparison of the effects of using commercial curricula with the effects of using the rational number project curriculum. Journal for Research in Mathematics Education, 33(2), 111-144. http://dx.doi.org/10.2307/749646

Deschenes, S., Cuban, L., \& Tyack, D. (2001). Mismatch: Historical perspectives on schools and students who don' t fit them. Teachers College Record, 103(4), 825-547. http://dx.doi.org/10.1111/0161-4681.00126

Empson, S. B. (2003). Low-performing students and teaching fractions for understanding: An interactional analysis. Journal for Research in Mathematics Education, 34(4), 305-343. http://dx.doi.org/10.2307/30034786

Entwisle, D., \& Alexander, K. (1996). Family type and children's growth in reading and math over the primary grades. Journal of Marriage and the Family, 58, 341-355. http://dx.doi.org/10.2307/353500

Fraivillig, J. (2001). Strategies for advancing children's mathematical thinking. Teaching Children Mathematics, $7(8), 454-459$.

Finnish National Board of Education. (2004). National Core Curriculum for Basic Education 2004. Retrieved March 20, 2010, from http://www.oph.fi/english/publications/2009/national_core_curricula_for_basci_education

Green, M., Piel, J., \& Flowers, C. (2008). Reversing education majors' arithmetic misconceptions with short-term instruction using manipulatives. North Carolina at Charlotte: Heldref Publications.

Gutstein, E. (2003). Teaching and learning mathematics for social justice in an urban, Latino school. Journal for Research in Mathematics Education, 34(1), 37-73. http://dx.doi.org/10.2307/30034699 
Hannula, M. S., Maijala, H., \& Pehkonen, E. (2004). Development of understanding and self-confidence in mathematics; Grades 5-8. In M. J. Høines, \& A. B. Fuglestad (Eds.), Proceedings of the $28^{\text {th }}$ Conference of the International Group for the Psychology of National Research Council, 2001). dered to be a key Mathematics Education (vol. 3, pp. 17-24). Bergen, Norway: Bergen University College.

Hiebert, J., \& Grouws, D. A. (2007). The effects of classroom mathematics teaching on students' learning. In F. Lester (Ed.), Second handbook of research on mathematics teaching and learning (pp. 371-404). Greenwich, CT: Information Age.

Huttenlocher, J., Jordan, N. C., \& Levine, S. C. (1994). A mental model for early arithmetic. Journal of Experimental Psychology: General, 123, 284-296. http://dx.doi.org/10.1037/0096-3445.123.3.284

Jordan, N. C., \& Levine, S. C. (2009). Socioeconomic variation, number competence, and mathematics learning difficulties in young children. Developmental Disabilities Research Reviews, 15, 60-68. http://dx.doi.org/10.1002/ddrr.46

Kennedy, P. A. (2000). Concrete representation and number line models: Connecting and extending. Journal of Developmental Education, 24(2), 2-8.

Kilpatrick, J., Swafford, J., \& Findell, B. (Eds.). (2001). Adding it up: Helping children learn mathematics. Washington, DC: National Academy Press.

Kö ller, O., Baumert, J., \& Schnabel, K. (2001). Does interest matter? The relationship between academic interest and achievement in mathematics. Journal for Research in Mathematics Education, 32, 448-470.

Lai, M.-L., Baroody, A. J., \& Johnson, A. (2008). Fostering preschoolers' understanding of the addition-subtraction inverse principle. Cognitive Development, 23(1), 216-235. http://dx.doi.org/10.1016/j.cogdev.2007.06.002

Lubienski, S. T. (2003). Celebrating diversity or denying disparities: A critical assessment. Educational Researcher, 32(8), 30-38. http://dx.doi.org/10.3102/0013189X032008030

Lubienski, S. T. (2007). Research, reform and equity in U.S. Mathematics Education. In N. Nasir, \& P. Cobb (Eds.), Improving Access to Mathematics: Diversity and Equity in the Classroom (pp. 10-23). New York: Teachers College Press.

Marsh, H. W., Trautwein, U., Lüdtke, O., Köller, O., \& Baumert, J. (2005). Academic self-concept, interest, grades and standardized test scores: Reciprocal effects models of causal ordering. Child Development, 76, 297-416. http://dx.doi.org/10.1111/j.1467-8624.2005.00853.x

Ministry of Education in Taiwan. (2010). Twelve-year joint mathematics curricula plan in Taiwan. Taiwan: Author. (In Chinese).

Ministry of Interior Social Affairs. (2012). Conditions and family property limits of the 100 annual low-income household category. Retrieved from http://sowf.moi.gov.tw/10/news/101\%E5\%B9\%B4\%E5\%BA\%A6\%E4\%BD\%8E\%E6\%94\%B6\%E5\%85\% A5\%Е6\%88\%B6\%Е9\%A1\%9E\%E5\%88\%A5\%Е6\%A2\%9D\%E4\%BB\%B6\%E4\%B8\%80\%Е8\%A6\%BD $\% \mathrm{E} 8 \% \mathrm{~A} 1 \% \mathrm{~A} 8 . \mathrm{htm}$

Morais, A., \& Neves, I. (2001). Pedagogic social contexts: Studies for a sociology of learning. In A. Morais, A. I. Neves, B. Davies, \& H. Daniels (Eds.), Towards a sociology of pedagogy: The contribution of Basil Nerstein to research (pp. 185-220). New York: Peter Lang.

Mullis, I. V. S., Martin, M. O., Gonzalez, E. J., \& Chrostowski, S. J. (2004). TIMSS 2003 International Mathematics Report: Findings from IEA's trends in international mathematics and science study at the fourth and eighth Grades. MA: Boston College.

Mullis, I. V. S., Martin, M. O., \& Pierre, F. (2009). TIMSS 2007 international mathematics report: Findings from IEA's trends in international mathematics and science study at the fourth and eighth grades. MA: Boston College.

Nasir, N., \& Cobb, P. (Eds.). (2007). Improving Access to Mathematics: Diversity and Equity in the Classroom. New York: Teachers College Press.

National Council of Teachers of Mathematics. (2000). The Principles and Standards for School Mathematics. Reston, VA: NCTM. 
National Research Council. (2001). Adding it up: Helping children learn mathematics. In J. Kilpatrick, J. Swafford, \& B. Findell (Eds.), Mathematics Learning Study Committee, Center for Education, Division of Behavioral and Social Science and Education (pp. 231-254). Washington, DC: National Academy Press.

O' Connor, M. C. (2002). "Can any fraction be turned into a decimal?" A case study of a mathematical group discussion. Educational Studies in Mathematics, 46, 143-185. http://dx.doi.org/10.1023/A:1014041308444

OECD. (2009). PISA 2006 technical report. Paris: Author. http://dx.doi.org/10.1787/9789264048096-en

Pogrow, S. (2009). Accelerate the learning of 4th and 5th graders born into poverty. Phi Delta Kappan, 90(6), 408-412.

Ruddell, R. B. (1999). Teaching Children to Read and Write: Becoming an Influential Teacher (2nd ed.). Boston: Allyn and Bacon.

Schoenfeld, A. H. (2002). Making mathematics work for all children: Issues of standards, testing, and equity. Educational Researcher, 31, 13-25. http://dx.doi.org/10.3102/0013189X031001013

Skovsmose, O., \& Valero, P. (2002). Democratic access to powerful mathematical ideas. In L. English (Ed.), Handbook of International Research in Mathematics Education (pp. 383-407). Mahwah, NJ: Erlbaum.

Starkey, P., \& Klein, A. (2000). Fostering parental support for children's mathematical development: An intervention with Head Start families. Early Education and Development, 11, 659-680. http://dx.doi.org/10.1207/s15566935eed1105_7

Starkey, P., Klein, A., \& Wakeley, A. (2004). Enhancing young children's mathematical knowledge through a pre-kindergarten mathematics intervention. Early Childhood Research Quarterly, 19, 99-120. http://dx.doi.org/10.1016/j.ecresq.2004.01.002

Stein, M. K., Remillard, J., \& Smith, M. S. (2007). How curriculum influences student learning. In F. Lester (Ed.), Second handbook of research on mathematics teaching and learning (pp. 319-369). Greenwich, CT: Information Age.

Stipek, D. J., \& Ryan, R. H. (1997). Economically disadvantaged preschoolers: Ready to learn but further to go. Developmental Psychology, 33, 711-723. http://dx.doi.org/10.1037/0012-1649.33.4.711

Strom, D., Kemeny, V., Lehrer, R, \& Forman, E. (2001). Visualizing the emergent structure of children' $s$ mathematical argument. Cognitive Science, 25, 733-773. http://dx.doi.org/10.1207/s15516709cog2505_6

Walkerdine, V. (1998). Counting Girls Out (Studies in Mathematics Education). Falmer Press, London: UK.

Yang, D. C. (2006). Developing number sense through real-life situations in school of Taiwan. Teaching Children Mathematics, 13(2), 104-110.

Yang, D. C., \& Li, F. M. (2008). An investigation of 3rd grade Taiwanese students' performance in number sense. Educational Studies, 34(5), 443-455. http://dx.doi.org/10.1080/03055690802288494

Yang, D. C., \& Wu, W. R. (2010). The study of number sense realistic activities integrated into third-grade math classes in Taiwan. The Journal of Educational Research, 103(6), 379-392. http://dx.doi.org/10.1080/00220670903383010

Yao, R. F., \& Yang, D. C. (2010). Creating appropriate mathematics learning environments for disadvantaged students through remedial instructional modules. The second annual Asian.

Conference on Education. (ACE 2010). Osaka, Japan. Dec 03 05, 2010. 


\section{Appendix}

\section{Paper-and-Pencil Tests for Basic Mathematics Competence}

1. A number of tea cups and operations)

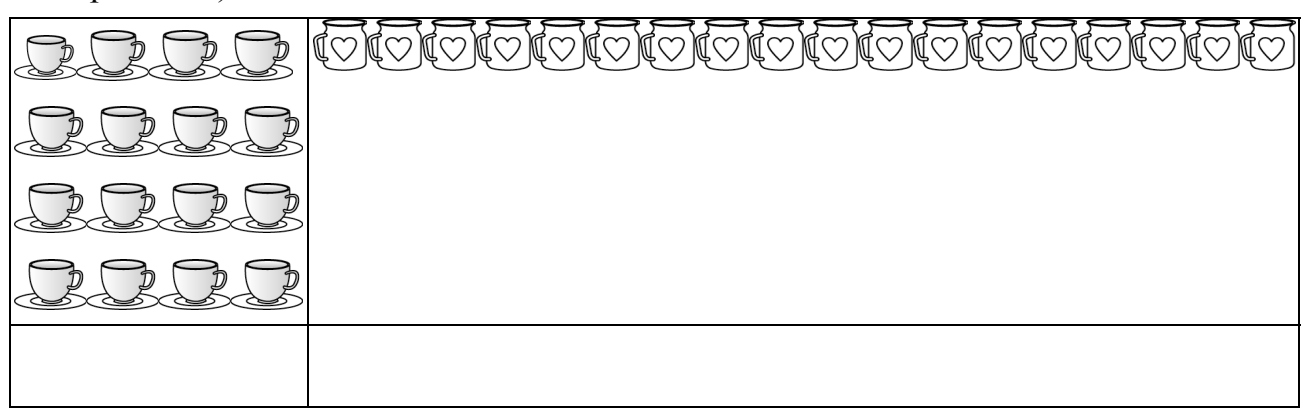

2. Please color the 16 th circle in the row below. (Number and operations)

90000000000000000000

$\downarrow$

The $1^{\text {st }}$ circle starts here.

3. Please fill in the blanks below with the correct time.(Measurement)

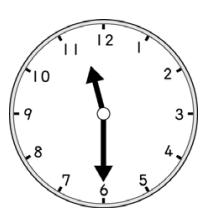

( ) Half past

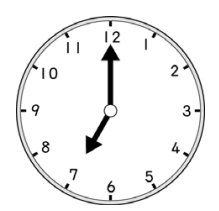

( ) o’ clock

4.

1) Please check the LONGEST arrow and fill in the box to indicate the SHORTEST arrow (Measurement)

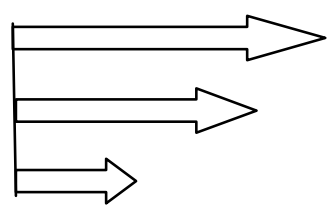

2) Please check the LONGEST string and fill in the box to indicate the SHORTEST string below. (Measurement)

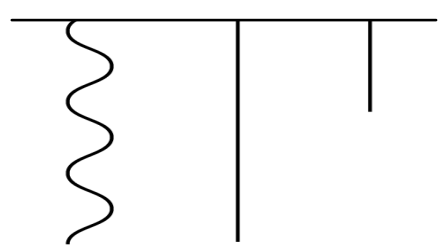


5. Please check the curves and fill in the box(es) to indicate the straight lines below. (Geometry)
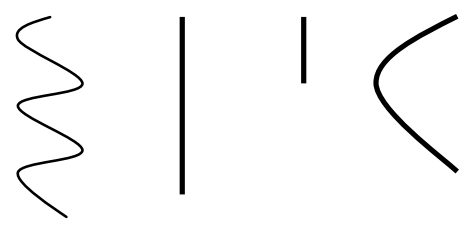

6. Count the shapes and then fill in the blanks with the correct numbers. (Geometry)

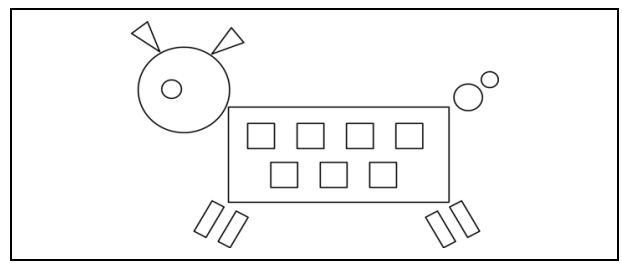

\begin{tabular}{|l|l|l|}
\hline Circles & Squares & Triangles \\
\hline & & \\
\hline
\end{tabular}

7. Please fill in the blanks below with correct names. (Geometry)

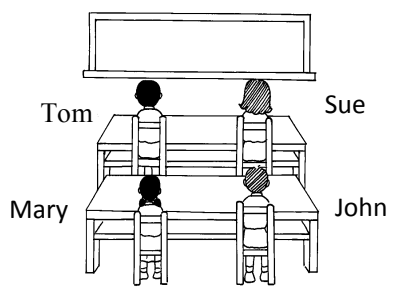

1) ( ) sits behind Tom.

2) ( ) sits to the right of Mary.

3) Who sits closer to the blackboard, Sue or John? ( )

8.

1) $4+3=(\quad) \quad$ (Number and operations)

2) $7-4=(\quad)$ (Number and operations)

3) $3+2=1+(\quad)$ (Pre-algebra)

4) $6+3=10-(\quad)$ (Pre-algebra)

9. Please fill in the blanks below with the correct numbers.

1) 7 lego blocks can be broken down into 5 blocks and ( ) blocks. (Pre-algebra)

2) 3 lego blocks and ( ) lego blocks make 9 lego blocks. (Pre-algebra)

10. Originally John has 1 dollar and his mother gives him 8 more dollars. Originally Susan has 3 dollars and then her mother gives her some more money. Now, John and Susan have exactly the same amount of money. Please figure out how many dollars Susan got from her mother. (pre-algebra) 


\section{Copyrights}

Copyright for this article is retained by the author(s), with first publication rights granted to the journal.

This is an open-access article distributed under the terms and conditions of the Creative Commons Attribution license (http://creativecommons.org/licenses/by/3.0/). 